\title{
Human HLA Class I- and HLA Class II-Restricted Cloned Cytotoxic T Lymphocytes Identify a Cluster of Epitopes on the Measles Virus Fusion Protein
}

\author{
ROBERT S. VAN BINNENDIJK, ${ }^{1 *}$ JOSÉ P. M. VERSTEEG-VAN OOSTEN, ${ }^{1}$ MARTIEN C. M. POELEN, ${ }^{1}$ \\ HUMPHREY F. BRUGGHE, ${ }^{2}$ PETER HOOGERHOUT, ${ }^{2}$ ALBERT D. M. E. OSTERHAUS, ${ }^{1}$ \\ AND FONS G. C. M. UYTDEHAAG ${ }^{1}$ \\ Laboratory of Immunobiology ${ }^{1}$ and Department of Bacterial Vaccine Development, ${ }^{2}$ National Institute \\ of Public Health and Environmental Protection, P.O. Box 1, 3720 BA Bilthoven, The Netherlands
}

Received 23 October 1992/Accepted 13 January 1993

\begin{abstract}
The transmembrane fusion (F) glycoprotein of measles virus is an important target antigen of human HLA class I- and class II-restricted cytotoxic T lymphocytes (CTL). Genetically engineered F proteins and nested sets of synthetic peptides spanning the $F$ protein were used to determine sequences of $F$ recognized by a number of F-specific CTL clones. Combined N-and C-terminal deletions of the respective peptides revealed that human HLA class I and HLA class II-restricted CTL efficiently recognize nonapeptides or decapeptides representing epitopes of $F$. Three distinct sequences recognized by three different HLA class II (DQw1, DR2, and DR4/w53)-restricted CTL clones appear to cluster between amino acids 379 and 466 of $F$, thus defining an important $T$-cell epitope area of $F$. Within this same region, a nonamer peptide of $F$ was found to be recognized by an HLA-B27-restricted CTL clone, as expected on the basis of the structural homology between this peptide and other known HLA-B27 binding peptides.
\end{abstract}

The two measles virus (MV) envelope glycoproteins, the hemagglutinin $(\mathrm{H})$ and the fusion $(\mathrm{F})$ protein, are targets for immune recognition by the immune system of an infected human host (for reviews, see references 29,34 , and 38). The generation of biologically active antibodies against the glycoproteins, i.e., hemagglutination- and fusion-inhibiting antibodies and neutralizing antibodies induced by either infection with wild-type virus or vaccination with a live attenuated vaccine, usually confers lifelong protective immunity against measles $(4,9,12,24,25,36,46,57,59)$.

The failure of inactivated measles virus vaccines used thus far to protect against measles upon reexposure to the virus has been associated with an incomplete immune response against the $F$ protein $(32,33,35,37)$. This illustrates the importance of the presentation of $F$ in an immunogenic form in future inactivated vaccines (33). The rationale and the demands for the development of inactivated vaccines against measles have recently been formulated by a World Health Organization steering committee.

Identification of the immunogenic epitopes which are recognized by $\mathrm{B}$ - and $\mathrm{T}$-lymphocyte antigen receptors may be of crucial importance for vaccine development. $\mathrm{CD} 4^{+} \mathrm{T}$ lymphocytes which assist in the activation of B lymphocytes and in their differentiation to antibody-producing cells recognize processed fragments of endocytosed protein antigen presented by class II molecules of the major histocompatibility complex at the surface of antigen-presenting cells (APC). $\mathrm{CD}^{+}$cytotoxic T lymphocytes (CTL) eliminate virus-infected cells, since they express at their cell surface processed fragments of endogenously synthesized viral proteins which associate with class I major histocompatibility complex molecules (for reviews, see references 2, 50, and 61).

For a number of virus infections, including MV infection,

\footnotetext{
* Corresponding author.
}

a major role in eliminating virus-infected cells has also been attributed to $\mathrm{CD}^{+}$class II-restricted CTL $(11,17,18,26$, $47,60)$. However, we recently documented the predominance of $\mathrm{CD}^{+}$class I-restricted CTL in antiviral T-lymphocyte-mediated immunity (53).

In the present study, the epitope specificity and HLA restriction of cloned $F$ protein-specific human CTL were documented. With $\beta$-galactosidase fusion proteins expressing different regions of $F$ and a number of synthetic peptides, nonameric and decameric sequences representing class Iand class II-presentable epitopes clustering between amino acids (aa) 379 and 466 could be identified.

\section{MATERIALS AND METHODS}

Antigen preparations. (i) MV. Plaque-purified MV (Edmonston B strain) was cultured on Vero cells, and $10^{7} 50 \%$ tissue culture infective doses of MV per ml was routinely used to infect human Epstein-Barr virus-transformed B-lymphoblastoid cell lines (B-LCL).

(ii) $\mathbf{F}$. The $\mathrm{F}$ protein was purified from whole virus by solubilizing purified MV with octyl $\beta$-D-glucopyranoside ( $2 \%$ [wt/vol] octyl glucoside; Sigma Chemical Co., St. Louis, Mo.) and subjecting the resulting preparation to affinity chromatography with F-specific monoclonal antibody 7-21 coupled to CNBr-activated Sepharose 4B as described previously (6).

(iii) $\mathbf{F}$ - $\beta$-galactosidase fusion proteins. $\beta$-Galactosidase fusion proteins containing both the $\beta$-galactosidase protein and combined $\mathrm{C}$ - and $\mathrm{N}$-terminal fractions of $\mathrm{F}$ were expressed in Escherichia coli $\mathrm{AB} 1157$ from pEX3 constructs as previously described (8). A set of different deletions was selected on the basis of restriction and sequence analysis and sodium dodecyl sulfate-polyacrylamide gel electrophoresis (SDSPAGE) and Western blotting (immunoblotting) of the expressed proteins in $E$. coli. $E$. coli cells producing the various $\beta$-galactosidase fusion proteins were lysed with 
lysozyme $(1 \mathrm{~g} /$ liter $)$ for $40 \mathrm{~min}$ at $0^{\circ} \mathrm{C}$ and then treated for 5 min with $0.11 \%$ Triton $\mathrm{X}-100$ in $25 \mathrm{mM}$ Tris- $\mathrm{HCl}$, (pH 8.0)-10 mM EDTA-50 mM glucose at $0^{\circ} \mathrm{C}$. After centrifugation (20 min at $10,000 \mathrm{rpm}$ [Sorvall SS-34 rotor]), the pellet was resuspended in $0.1 \%$ Triton $\mathrm{X}-100-10 \mathrm{mM}$ Tris- $\mathrm{HCl}-0.1$ mM EDTA (pH 7.5). Triton X-100 was removed by centrifugation of the proteins through a $20 \%$ sucrose cushion $(10$ min at $10,000 \mathrm{rpm}$ [Sorvall SS-34 rotor]). The pellets were resuspended in phosphate-buffered saline (PBS) solution ( $\mathrm{pH}$ 7.2) and sonicated before they were used in proliferative T-cell assays. About $90 \%$ of the total protein in these preparations consisted of fusion proteins, as determined by SDS-PAGE and Western blot analysis.

(iv) F peptides. Peptides were assembled with an automated multiple peptide synthesizer equipped with a 48-column reaction block (AMS 422; ABIMED Analysen-Technik $\mathrm{GmbH}$, Langenfeld, Germany) and $N \alpha$-fluorenylmethoxycarbonyl (Fmoc)-protected $(1,10)$ amino acids (Novabiochem, Laufelfingen, Switzerland) as previously described (58). All peptides were prepared with acetylated $\mathrm{N}$ termini and C-terminal carboxamides. The peptides were deprotected and cleaved from the solid support (58) with trifluoroacetic acid in the presence of scavengers (as described in reference 1 but with a slight modification, i.e., water replaced the recommended phenol). The crude peptides (purity of 50 to $90 \%$ for 18 -meric peptides and $>85 \%$ for 12 -meric peptides, as determined by reverse-phase high-performance liquid chromatography analysis) were used in immunological experiments in concentrations of $10^{-9}$ to $10^{-5} \mathrm{M}$.

T-cell clones. The MV-specific human T-cell clones described in this article were established from peripheral blood mononuclear cells (PBMC) of three healthy adult individuals (donors 3, 4, and 5) and of two children (donors 1 and 2). PBMC were obtained from the children 4 weeks after clinical symptoms of measles were observed. All T-cell clones were generated from PBMC that were stimulated and cloned with autologous MV-infected B-LCL and were cultured in vitro as previously described $(52,53$; some of the $\mathrm{T}$-cell clones previously described have been renamed, and information regarding this redesignation can be obtained from corresponding author). Briefly, the T-cell clones were maintained in culture in 96-well round-bottomed microtiter plates (Greiner Labor Technik, Nürtingen, Germany) in $150 \mu l$ of RPMI 1640 supplemented with $10 \%$ (vol/vol) pooled human AB serum, $2 \mathrm{mM}$ L-glutamine, penicillin $(100 \mathrm{U} / \mathrm{ml})$, streptomycin $(100 \mu \mathrm{g} / \mathrm{ml}), 10^{-5} \mathrm{M} 2$-mercaptoethanol, and $20 \mathrm{U}$ of recombinant interleukin-2 (Boehringer, Mannheim, Germany) per $\mathrm{ml}$. Growing clones were expanded and kept at a density of $3 \times 10^{4}$ to $5 \times 10^{4}$ cells per well in the presence of recombinant interleukin-2 and were restimulated with MVinfected B-LCL every 10 to 14 days of culture.

Cytotoxicity assays. B-LCL were cultured and maintained in RPMI 1640 supplemented with $5 \%$ (vol/vol) fetal calf serum, $2 \mathrm{mM}$ L-glutamine, penicillin $(100 \mathrm{U} / \mathrm{ml})$, streptomycin $(100 \mu \mathrm{g} / \mathrm{ml})$, and $10^{-5} \mathrm{M} 2$-mercaptoethanol (referred to herein as complete medium). Autologous or HLA-matched B-LCL $\left(10^{6}\right.$ to $10^{7}$ cells) were infected for $24 \mathrm{~h}$ at $37^{\circ} \mathrm{C}$ with MV at a multiplicity of infection of 3.0. Alternatively, B-LCL were incubated during the CTL assay $(4 \mathrm{~h})$ with synthetic peptides $(10 \mathrm{nM}$ to $10 \mu \mathrm{M})$. T-cell clones were subsequently incubated with ${ }^{51} \mathrm{Cr}$-labeled B-LCL at effector cell-to-target cell ratios ranging from 3 to 6 . After $4 \mathrm{~h}$ of incubation at $37^{\circ} \mathrm{C}$, supernatants free from cells were collected from individual cultures, and the radioactivity in the supernatants was counted in a gamma counter. Spontaneous ${ }^{51} \mathrm{Cr}$ release (target cells only) and maximal ${ }^{51} \mathrm{Cr}$ release (target cells in 2\% Triton X-100) were used as control values in all assays. Results are expressed as the mean percentage of specific target cell lysis \pm the standard deviation of triplicate cultures.

Proliferative T-cell assays. Autologous PBMC and HLAtyped B-LCL were used as stimulator cells for proliferative responses of T-cell clones. PBMC were incubated for $3 \mathrm{~h}$ at $37^{\circ} \mathrm{C}$ with purified $\mathrm{F}(3 \mu \mathrm{g} / \mathrm{ml}), F-\beta$-galactosidase fusion proteins $(3 \mu \mathrm{g} / \mathrm{ml})$, or synthetic peptides $(10 \mathrm{nM}$ to $10 \mu \mathrm{M})$. The PBMC were then washed and gamma irradiated $(3,000$ rads). The B-LCL were incubated with the same antigens and by the same procedures as described above for the cytotoxicity assays. In addition, B-LCL were infected with one of two vaccinia virus recombinants: either a control vaccinia virus (vv-vsc8) or a vaccinia virus containing the full-length cDNA encoding MV F (vv-F37). Briefly, $10^{7}$ B-LCL were infected with vv-vsc8 or vv-F37 at a multiplicity of infection of 5.0 for $16 \mathrm{~h}$ at $37^{\circ} \mathrm{C}$. After antigen incubation, the B-LCL were washed and fixed for $15 \mathrm{~min}$ with $0.5 \%$ (wt/vol) paraformaldehyde in $1 \mathrm{mM}$ PBS (pH 7.2), treated for $15 \mathrm{~min}$ with $0.2 \mathrm{M}$ glycine in PBS and for $60 \mathrm{~min}$ with complete medium, and then used as stimulator cells. T-cell clones $\left(3 \times 10^{4}\right.$ cells per well) were subsequently cultured for 3 days at $37^{\circ} \mathrm{C}$ in the absence of recombinant interleukin- 2 with B-LCL $\left(2 \times 10^{4}\right.$ cells per well $)$ or PBMC $\left(10^{5}\right.$ per well) and pulsed with $0.5 \mu \mathrm{Ci}$ of $\left[{ }^{3} \mathrm{H}\right]$ thymidine over the last $18 \mathrm{~h}$ of culture. The cells were harvested, and the incorporated radioactivity was counted in a flatbed betascintillation counter (Pharmacia LKB, Uppsala, Sweden). Results are expressed as the mean counts per minute \pm standard deviation of triplicate cultures.

\section{RESULTS}

Generation of F glycoprotein-specific CTL clones. F-specific $T$-cell clones were generated in vitro from PBMC of five individuals by using autologous MV-infected B-LCL as APC. Although these procedures can yield clones recognizing different polypeptides of MV (52), all T-cell clones derived from two donors ( 3 and 5$)$ and some of the clones from three other donors $(1,2$, and 4$)$ appeared to recognize $F$. The present study focused on the identification of the specificities of six of these F-specific T-cell clones. Among these clones are four $\mathrm{CD}^{+}$T-cell clones (3-F94, 5-F2.1, 4-F76, and 4-F99) derived from three healthy adult individuals and two $\mathrm{CD}^{+}$T-cell clones (1-F20 and 2-F40) that were generated from PBMC obtained from two children 4 weeks after the onset of clinical symptoms of measles.

All T-cell clones showed an F-specific proliferative T-cell response to APC that were either pulsed with affinitypurified $F$ or infected with vaccinia virus expressing $F$ (vv-F37) (Table 1).

Analyses of the genetic restriction of antigen presentation revealed that the response of $\mathrm{CD}^{+}$T-cell clone 3-F94 is restricted to HLA-DRw53 of the DR4 or DR7 (Table 1), or DR9 (data not shown) haplotype: Another HLA-DR determinant (DR2) was required for the antigen-specific $T$-cell response of clone 5-F2.1 (Table 1) (52). Clone 4-F99 responds to $F$ in association with HLA-DQw1, which is present on DQ5- or DQ6-bearing APC (Table 1). The precise restriction element for clone 4-F76 could not be determined with the panel of APC used, although MV-specific T-cell responses of 4-F76 were inhibited by HLA-DQ-specific antibodies (52). All T-cell clones appeared to be efficient cytotoxic effector $\mathrm{T}$ lymphocytes in vitro (see references 52 and 54). 
TABLE 1. Genetic restriction and antigen specificity of F protein-specific CTL clones ${ }^{a}$

\begin{tabular}{|c|c|c|c|c|c|c|c|c|}
\hline \multirow{3}{*}{ APC } & \multirow{3}{*}{ Antigen } & \multirow{3}{*}{ HLA shared } & \multicolumn{6}{|c|}{ Proliferative T-cell response of T-cell clone of indicated phenotype } \\
\hline & & & \multicolumn{2}{|c|}{$\mathrm{CD}^{+}$} & \multicolumn{4}{|c|}{$\mathrm{CD}^{+}+$} \\
\hline & & & 1-F20 & 2-F40 & 3-F94 & 4-F76 & 4-F99 & 5-F2.1 \\
\hline B-LCL 1 & MV & Bw62, DR4/w53 & 43.9 & 0.1 & 67.7 & 0.1 & 0.1 & $\mathrm{NT}^{b}$ \\
\hline B-LCL 2 & MV & B27, DQ5/w1, DR4/w53 & 0.1 & 47.2 & 33.4 & 0.2 & 20.8 & NT \\
\hline B-LCL 3 & MV & DR4/w53 & 0.0 & 0.1 & 86.2 & 0.1 & 0.1 & NT \\
\hline B-LCL 4 & MV & B27, DQ6/w1, DR2 & 0.0 & 49.8 & 0.1 & 30.1 & 19.6 & NT \\
\hline B-LCL 5 & MV & DQ6/w1, DR2 & NT & NT & NT & 0.1 & 16.8 & 20.1 \\
\hline B-LCL 6 & MV & B27, Bw62, DR4/w53 & 29.6 & 56.7 & 47.1 & 0.2 & 0.1 & NT \\
\hline B-LCL 7 & MV & B27, DQ5/w1, DR7/w53 & 0.1 & 38.0 & 72.1 & 0.1 & 34.2 & NT \\
\hline $\begin{array}{l}\text { Uninfected autologous } \\
\text { B-LCL from all } \\
\text { donors }\end{array}$ & & & $<0.3$ & $<0.3$ & $<0.3$ & $<0.3$ & $<0.3$ & $<0.3$ \\
\hline B-LCL & vv-vsc8 & Autologous & 0.7 & 0.5 & 1.9 & NT & NT & NT \\
\hline B-LCL & vv-F37 & Autologous & 32.8 & 23.5 & 27.5 & NT & NT & NT \\
\hline PBMC & -- & Autologous & NT & NT & 0.9 & 0.8 & 0.7 & 1.1 \\
\hline PBMC & $\mathbf{F}$ & Autologous & NT & NT & 31.5 & 43.9 & 49.9 & 18.9 \\
\hline
\end{tabular}

${ }^{a}$ Shown are proliferative T-cell responses of T-cell clones to the following APC: HLA-typed B-LCL, either uninfected or infected for 24 h with MV at a multiplicity of infection of 3 ; autologous B-LCL, infected for $18 \mathrm{~h}$ with vaccinia virus expressing either control antigen (vv-vsc8) or F (vv-F37) at a multiplicity of infection of 5; and autologous PBMC, either untreated (--) or pulsed for $3 \mathrm{~h}$ with affinity-purified $\mathrm{F}$ at $3 \mu \mathrm{g} / \mathrm{ml}$. Responses are shown as the mean counts per minute $\left(10^{3}\right)$ of triplicate cultures (standard deviations are within $10 \%$ of the means) (see also references 52 and 54 ).

$b$ NT, not tested.

Definition of the regions of $F$ recognized by $F$-specific $T$-cell clones. In order to enable the identification of localization of $T$-cell epitopes that are recognized by $F$-specific $T$-cell clones, we constructed a set of $\beta$-galactosidase fusion proteins, containing various $F$ amino acid sequences of different lengths. All HLA class II-restricted F-specific T-cell clones showed a proliferative $\mathrm{T}$-cell response to the $\beta$-galactosidase fusion protein containing the major part of $F$ (aa 2 to 513) (Fig. 1). Proliferative T-cell responses to other $\beta$-galactosidase fusion proteins showed that all clones responded to different regions of $F$, i.e., approximately aa 428 to 457 for clone 3-F94, aa 2 to 231 for the DQ-restricted clone 4-F76, aa 409 to 428 for clone 4-F99, and aa 358 to 409 for clone 5-F2.1.

Neither purified $\mathbf{F}$ nor the $\mathbf{F}-\boldsymbol{\beta}$-galactosidase fusion proteins can be used to analyze the presentation of $F$ to the $\mathrm{CD}^{+}$T-cell clones 2-F40 and 1-F20, as uptake of these exogenous antigens by APC does not result in the generation of an HLA class I-presentable peptide (reference 54 and data not shown).

HLA class II-restricted F-specific CTL clones recognize a cluster of epitopes between aa 379 and 463. Three clones (5-F2.1, 4-F99, and 3-F94) recognized epitopes of F which are located between approximately aa 358 and 457. A number of peptides overlapping this region were synthesized. By simultaneous peptide synthesis, 18-mer peptides of F with 12-mer sequence overlaps in successive peptides were synthesized for clone 5-F2.1 and 12-mer sequences with nonamer overlaps were synthesized for clones 4-F99 and 3-F94. With peptide-pulsed B-LCL or peptide-pulsed fresh autologous PBMC, proliferative and cytotoxic T-cell responses could be demonstrated for all $\mathrm{T}$-cell clones. Clone 4-F99, which had a poor response toward peptide-pulsed B-LCL in a cytotoxic assay, responded well in a prolifera-

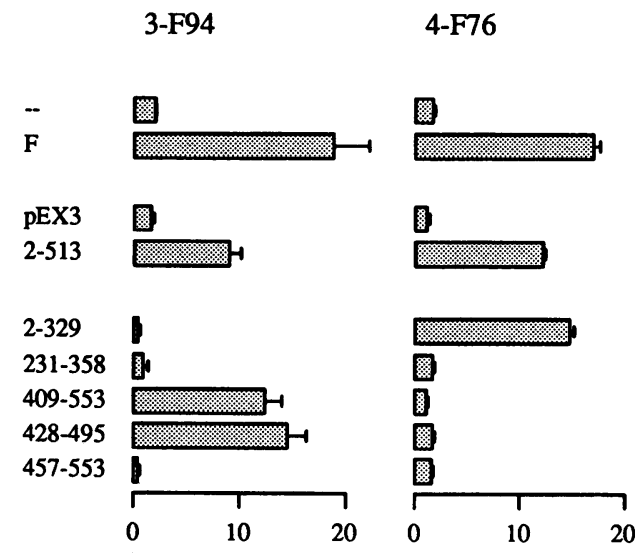

4-F99
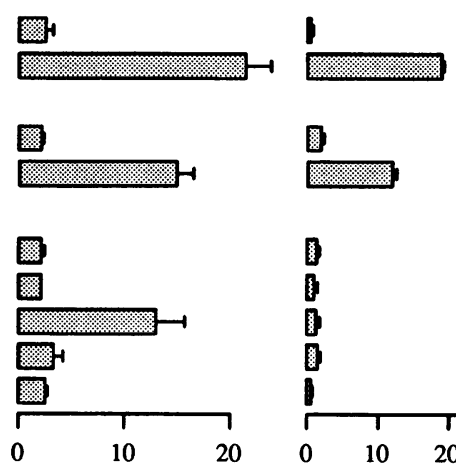

5-F2.1

a

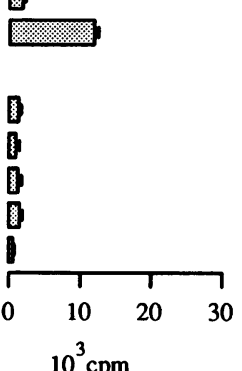

FIG. 1. Regions of F recognized by HLA class II-restricted CTL clones. We measured proliferative T-cell responses of T-cell clones to autologous PBMC either untreated (--), pulsed for $3 \mathrm{~h}$ with $3 \mu \mathrm{g}$ of affinity-purified $\mathrm{F}(\mathrm{F})$ per $\mathrm{ml}$, or pulsed for $3 \mathrm{~h}$ with $3 \mu \mathrm{g}$ of $\beta$-galactosidase fusion proteins, containing different polypeptide sequences of $\mathrm{F}$, per $\mathrm{ml}$. 
amino acid sequence:

clone 5-F2.1

$\begin{array}{cccc}370 & 380 & 390 & 400 \\ 1 & 1 & 1 & 1 \\ \text {. KSCARTLVSGSFGNRFILSQGNLIANCASILCKCYT. . }\end{array}$

KSCARTLVSGSFGNRFIL

LVSGSFGNRFILSQGNLI

GNRFILSQGNLIANCASI

SQGNLIANCASILCKCYT

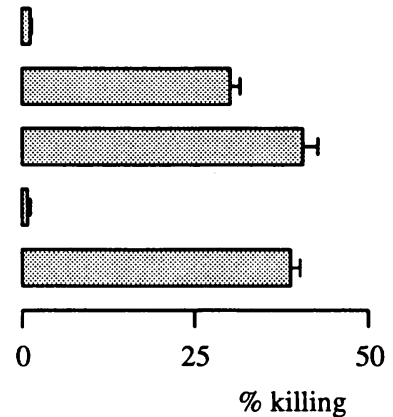

$\%$ killing

FIG. 2. Peptide specificity of HLA-DR2-restricted T-clone 5-F2.1. The CTL responses (effector cell-to-target cell ratio, 5) to B-LCL infected with MV and to B-LCL pulsed with four 18-meric peptides $(1 \mu \mathrm{M})$ from a peptide synthesis covering aa 343 to 426 of $F$ are shown. The underlined sequence shows the overlapping sequence in two successive peptides.

tive T-cell assay in which autologous PBMC were used as APC.

The epitope of $F$ recognized by clone 5-F2.1 was present in two successive 18-mers spanning aa 379 to 390 of $F$ (Fig. 2). Clone 4-F99 responded to one of the 12-mer peptides representing aa 425 to 436 , whereas 3-F94 recognized two successive peptides representing aa 452 to 463 and 455 to 466 , respectively (Fig. 3 ). The $F$ epitope recognized by clone 4-F76 and located near the $\mathrm{N}$ terminus of $\mathrm{F}$ (approximately aa 2 to 231 [Fig. 1]) is currently being studied.

Together, these data demonstrate the existence of a cluster of at least three T-cell epitopes located between aa 379 and 466 of $F$ that are recognized by a number of CTL clones in association with various HLA class II molecules.

F-derived nonamers and decamers are efficiently recognized by DQw1- and DR4/w53-restricted T-cell clones. Sequence analysis of peptides eluted from murine and human major histocompatibility complex class II molecules has revealed that such peptides range from a 13 to 17 aa in length $(16,45)$. Although HLA class II-restricted T cells can be stimulated by peptides with a relatively short length of 8 to 10 aa, longer peptides are usually more effective (3). We also found that relatively short synthetic peptides of $F$ can be presented to HLA class II-restricted T-cell clones. In the case of clone 3-F94, two peptides containing a sequence of 9 aa were able to stimulate the clone. These data indicate that relatively short synthetic peptides of $\mathrm{F}$ may be presented to T-cell clones. The peptides recognized by clones 4-F99 and 3-F94 were therefore minimized in length by constructing a set of nested peptides, with either $\mathrm{C}$ - or $\mathrm{N}$-terminal deletions.

amino acid sequence:
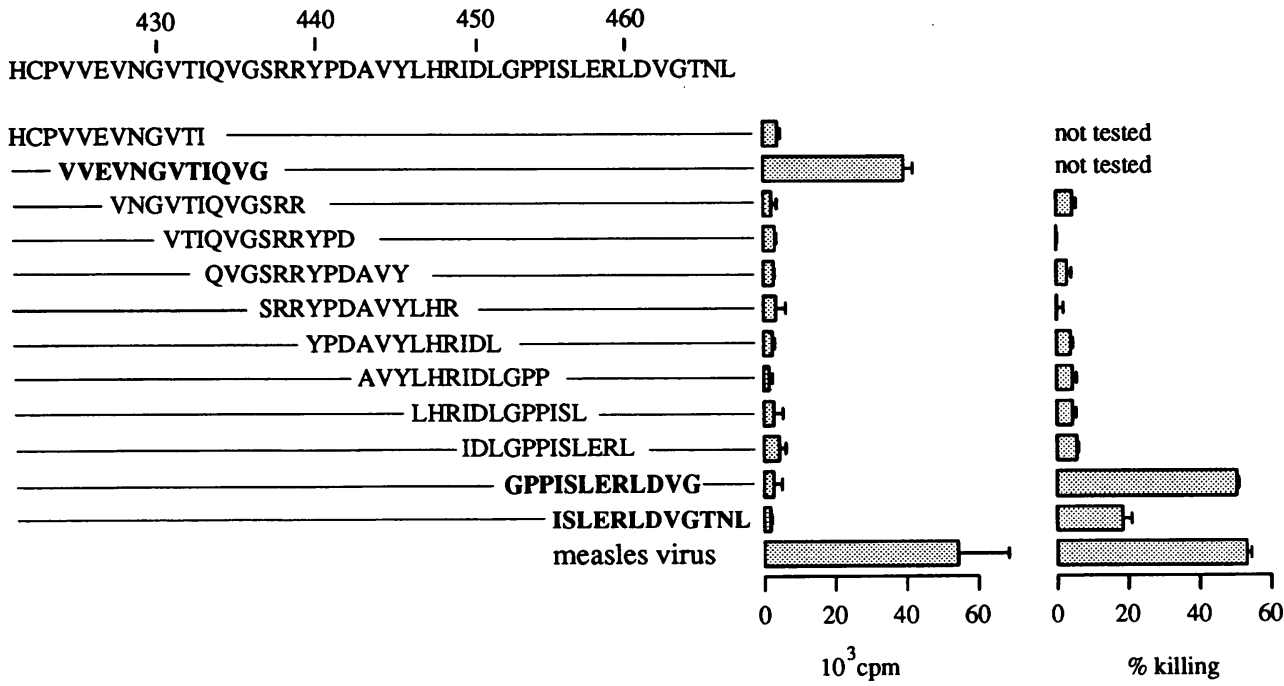

FIG. 3. Peptide specificities of clones 4-F99 and 3-F94. The CTL responses (effector cell-to-target cell ratio, 5) to B-LCL infected with MV and to B-LCL pulsed with 12-meric peptides $(1 \mu \mathrm{M})$ covering aa 422 to 466 of $F$ are shown. Clone 4-F99 was tested in a proliferative assay with autologous PBMC pulsed with the same peptides $(1 \mu \mathrm{M})$ or with $\mathrm{UV}$-irradiated MV $(10 \mu \mathrm{g} / \mathrm{ml}$; see reference 52$)$. Boldface sequences represent peptides that are recognized. 

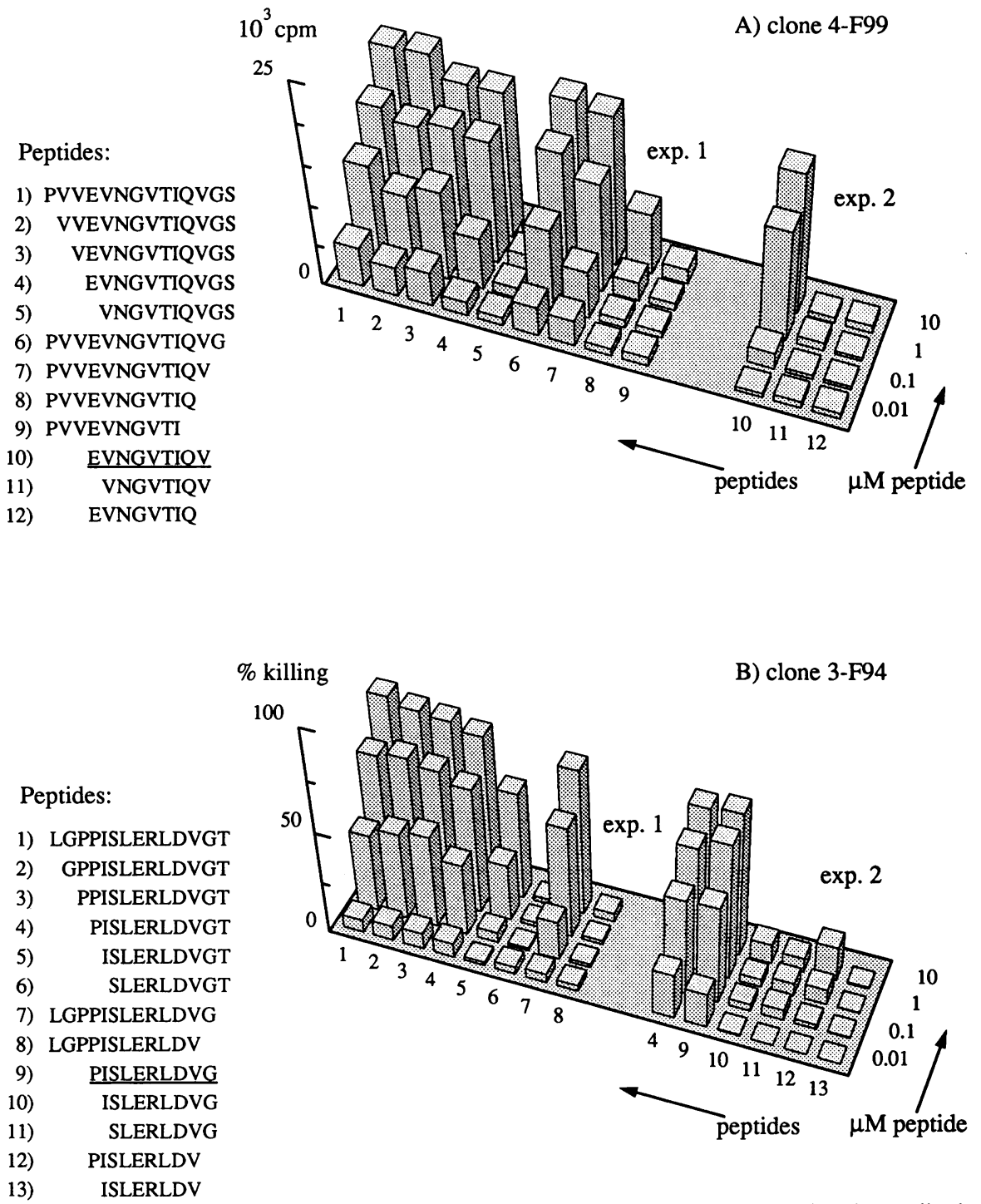

FIG. 4. Minimal lengths of peptides required for the presentation of $\mathrm{F}$ to HLA-DQw1-restricted T-cell clone 4-F99 (A) and to HLA-DR4/w53-restricted CTL clone 3-F94 (B). C- and N-terminally deleted peptides containing the epitopes ( $x$ axis) were tested in four different concentrations ( $y$ axis) in a proliferative T-cell assay (A) or in a CTL assay (B) with peptide-pulsed autologous PBMC or B-LCL, respectively, as APC. The T-cell responses ( $z$ axis) are shown; standard deviations are within $10 \%$ of the mean counts per minute. exp., experiment. Minimal-length peptides recognized are underlined.

Cytotoxic (3-F94) and proliferative (4-F99) T-cell responses toward the peptides were measured with a range of peptide concentrations (Fig. 4, experiment 1). Depending on the outcome of this experiment, a second set of nested peptides with combined $\mathrm{C}$ - and $\mathrm{N}$-terminal deletions were synthesized in order to define the actual minimal sequence of these peptides that could be presented to these clones (Fig. 4, experiment 2). From these experiments, it can be concluded that the minimal peptide sequence efficiently recognized by clone 4-F99 is the nonapeptide EVNGVTIQV, representing aa 427 to 435 of $F$ (Fig. 4). The minimal peptide recognized by clone 3-F94 turned out to be the decamer PISLERLDVG, representing aa 454 to 463 of $F$, and this peptide was as efficiently recognized as the longer ones covering this sequence (Fig. 4). Although the amino acid proline at the first position of the 11-mer PISLERLDVGT can be deleted, the resulting peptide ISLERLDVGT required at least a 10 -fold- higher peptide concentration to sensitize targets for killing by the clone. Deletion of this residue in the decamer PISLERLDVG, resulting in peptide ISLERLDVG, abolished the capacity to be recognized by clone 3-F94 (Fig. 4).

The nonapeptide RRYPDAVYL is recognized by clone 2-F40 and shows considerable homology to other HLA-B27 binding peptides. Among the HLA class I-restricted F-specific CTL clones that were generated from the PBMC of children with acute measles, clone 2-F40 recognized an F epitope presented by HLA-B27 molecules. Amino acid sequence analyses of endogenous peptides isolated from HLA-B27 molecules and of viral peptides which bind to HLA-B27 molecules have revealed a peptide binding motif for HLA-B27 molecules (20). This motif is characterized by an arginine found in all such peptides at position 2 and by a preference for charged amino acids at positions 1 and 9 . Furthermore, hydrophobic and nonpolar or small polar 
amino acid sequence:

clone 2-F40

$\begin{array}{cccc}430 & 440 & 450 & 460 \\ 1 & 1 & 1 \\ \text { VNGVTIQVGSRRYPDAVYLHRIDLGPPISLERLDVGTNL }\end{array}$

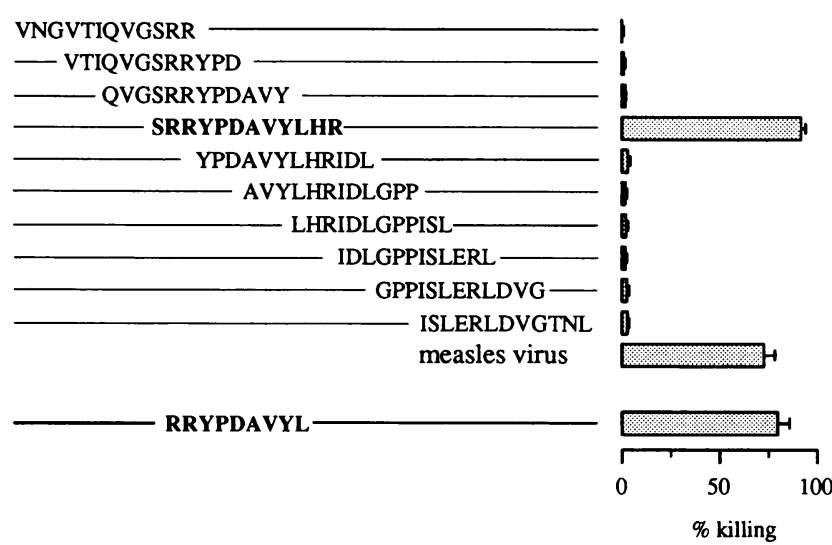

FIG. 5. HLA-B27 restricted CTL-clone 2-F40 responds to the nonamer peptide RRYPDAVYL of F (aa 438 to 446). The CTLresponses (effector cell-to-target cell ratio, 3) to B-LCL infected with MV, B-LCL pulsed with 12-meric peptides $(1 \mu \mathrm{M})$ from a peptide synthesis covering aa 428 to 466 of $F$, and the nonamer peptide RRYPDAVYL representing aa 438 to 446 of $F$ are shown.

amino acid residues are often found at positions 3 and 6 , respectively $(15,20,31)$. These findings prompted us to search for an HLA-B27 binding motif in the F sequence. The only nonamer sequence of $\mathrm{F}$ which fulfilled these criteria was the sequence consisting of aa 438 to 446 (RRYPDAVYL). Among the sets of peptides used to map class II-presentable peptides, a 12-mer peptide containing this sequence (SRRYPDAVYLHR) was actually found to stimulate the HLA-B27 restricted CTL clone 2-F40 (Fig. 5). The nonamer peptide RRYPDAVYL was subsequently synthesized, and clone 2-F40 responded to this peptide as well (Fig. 5). RRYPDAVYL indeed showed considerable homology to other HLA-B27 binding peptides, i.e., a positively charged residue at position 1 , an arginine at position 2 , a hydrophobic amino acid at position 3 , and a small hydrophobic residue at position 6 . The other positions of $F$ residues 438 to 446 are fairly heterogeneous in comparison with other HLA-B27 binding peptides (Fig. 6).

\section{DISCUSSION}

Analysis of antigen-specific proliferative and CTL responses in healthy adults and in a patient with multiple sclerosis seropositive for MV showed the presence of class II-presentable T-cell determinants on the structural proteins of MV that are recognized by $\mathrm{CD}^{+}$CTL $(19,43,44)$. From experience with inactivated measles virus vaccines, it has become apparent that the $F$ protein is indispensable for the induction of long-lasting protective immunity against $\mathrm{MV}$ $(33,34,38)$. In agreement with this, we have previously shown that the $\mathrm{F}$ protein is an important target protein for major histocompatibility complex class II-restricted CTL cloned from MV-seropositive healthy adults with a history of measles (52). Recently, Partidos and Steward (42) showed, on the basis of a predictive HLA-DR1 binding peptide motif, that the sequence consisting of 288 to 302 of $F$ contained a promiscuous T-cell epitope.

In this article, we show that in addition to the HLA-DR1 binding motif in aa 288 to 302 , the $F$ protein harbors at least two class II-presentable peptides in aa 379 to 463 that are recognized by cloned $C D 4^{+}$CTL in association with different DR alleles. It is clear from Fig. 4 that the truncated peptide PISLERLDVG is the core sequence that apparently binds to HLA-DR. Consistent with the tentative DR binding motifs proposed by several groups $(14,22,40,41)$, this peptide contains hydrophobic residues at positions 2 and 9 and a noncharged residue at position 7 (Fig. 6). Further truncation of the amino terminus reduced the target-sensitizing capacity of the peptide by more than 1,000 -fold. This strongly argues against the presence of isoleucine instead of proline at position 1 . The 12 -mer sequence recognized by clone 5-F2.1 in association with DR2 contains the amino acid sequence FILSQGNLI, which fits virtually all of the criteria for DR binding patterns (Fig. 6): hydrophobic residues at positions $1,2,8$, and $9(14,22)$, glutamine at position $5(22)$, and a small residue at position $3(40)$. Binding studies with this peptide will be necessary to confirm its expected affinity for DR2. When examining a large collection of class II binding determinants, including a DQ-restricted sequence of Plasmodium falciparum gp190 A1 (5), Hill et al. (14) observed that a large portion could be aligned to give a pattern

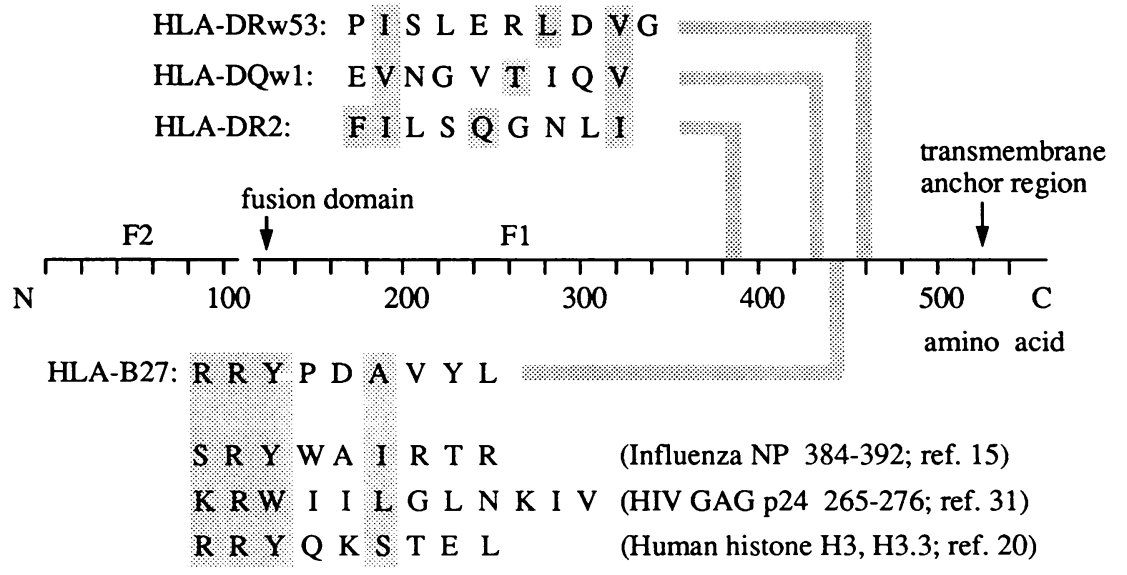

FIG. 6. Peptide binding motifs of class I- and class II-presentable peptides of F. NP, nucleoprotein; HIV, human immunodeficiency virus. Shaded regions are explained in the Discussion. 
of an amino-terminal hydrophobic residue and a small residue at position 6 . When the core sequence of the DQw1restricted peptide EVNGVTIQV recognized by clone 4-F99 was examined, we observed that it could be aligned to reveal the same pattern (Fig. 6). Additionally, a hydrophobic residue was found at position 9 . Thus the sequence consisting of aa 379 to 463 of $F$ contains three T-cell epitopes that all have common features of class II binders: hydrophobic residues at positions 1 and/or 2 and at position 9 .

On the basis of analysis of the T-cell response in MVseropositive adults and in a patient with multiple sclerosis, it has been argued that CTL directed against MV are primarily $\mathrm{CD}^{+}$class II restricted $(17,18)$, despite earlier analyses of the T-cell response toward MV which showed evidence for $\mathrm{CD}^{+}$class I-restricted CTL activity against MV $(21,23$, 48). Recently we have demonstrated that in recovery from acute measles, $\mathrm{CD}^{+}$class I-restricted CTL are the predominant MV-specific effector cells (53). Moreover, we showed that $\mathrm{CD}^{+}$class I-restricted MV-specific CTL can also be cloned from healthy MV-seropositive adults (52). One of the CTL clones, 2-F40 (from a patient with acute measles), showed an HLA-B27-restricted recognition of F (Fig. 5). A search based on a known HLA-B27 binding peptide motif revealed a nonamer sequence in $F$ (aa 438 to 446) consistent with such a motif (20). This sequence, RRYPDAVYL, contains an arginine anchor at position 2, another arginine at position 1 , a tyrosine at position 3 , and a small hydrophobic residue on position 6 (Fig. 6). Using the set of 12-mer peptides with a 3-aa overlap spanning this sequence, we found that only the peptide containing this entire nonamer sequence sensitized targets for killing by the CTL clone. Subsequently, we showed that it was indeed the nonapeptide that contained the core sequence (Fig. 5).

Collectively, our data show that the sequence consisting of aa 379 to 463 of F contains a cluster of epitopes recognizable by $\mathrm{CD}^{+}$as well as $\mathrm{CD}^{+}$CTL in association with different class II and class I molecules, respectively. Further analysis of $F$ for the presence of class $I$ binding epitopes in particular is required, as F or parts of it will be indispensable components of future inactivated vaccines against measles. Our recent results showing that $\mathrm{F}$ incorporated in immunestimulating complexes (ISCOMs) can sensitize targets for class II- as well as class I-restricted killing by CTL (54), together with the evidence that ISCOMs containing viral glycoproteins can induce virus-neutralizing antibodies and protection $(7,27,28,39,51,55,56)$ and can prime for class I-restricted CTL $(13,30,49)$, indicate the potential of an ISCOM-based vaccine containing $F$ in addition to other structural proteins of MV.

\section{ACKNOWLEDGMENTS}

We thank Bernard Moss and Willy Spaan for recombinant vaccinia viruses (vv-vsc8 and vv-F37, respectively) and Conny Kruyssen for help in preparing the manuscript.

This work was supported by the Technology Foundation (STW), Utrecht, The Netherlands (grant number 77.1399).

\section{REFERENCES}

1. Atherton, E., and R. C. Sheppard. 1989. Solid phase peptide synthesis: a practical approach. IRL Press at Oxford University Press, Oxford.

2. Braciale, T. J., and V. L. Braciale. 1991. Antigen presentation: structural themes and functional variations. Immunol. Today 12:124-129.

3. Cease, K. B., I. Berkower, J. York-Jolley, and J. A. Berzofsky. 1986. T cell clones specific for an amphipathic alpha helical region of sperm whale myoglobulin show different fine specific- ities for synthetic peptides: a multi/single structure interpretation of dominance. J. Exp. Med. 164:1779-1784.

4. Chen, R. T., L. E. Markowitz, P. Albrecht, J. A. Stewart, L. M. Mofenson, S. R. Preblud, and W. A. Orenstein. 1990. Measles antibody: reevaluation of protective titers. J. Infect. Dis. 162: 1036-1042.

5. Chrisanti, A., H. M. Muller, C. Hilbich, F. Sinigaglia, H. Matile, M. McKay, J. Scaife, K. Beyreuther, and H. Bujard. 1988. Epitopes recognized by human T-cells map within the conserved part of the GP190 of P. falciparum. Science 240:1324 1326.

6. De Vries, P., R. S. Van Binnendijk, P. van der Marel, E. C. Beuvery, A. L. Van Wezel, H. O. Voorma, F. G. C. M. UytdeHaag, and A. D. M. E. Osterhaus. 1987. Inhibition of measles virus induced cell-cell fusion with a monoclonal antibody directed against the hemagglutinin. Viral Immunol. 1:2534.

7. De Vries, P., R. S. Van Binnendijk, P. van der Marel, A. L. Van Wezel, H. O. Voorma, B. Sundquist, F. G. C. M. UytdeHaag, and A. D. M. E. Osterhaus. 1988. Measles virus fusion protein presented in immune-stimulating complex (iscom) induces haemolysis-inhibiting and fusion-inhibiting antibodies, virus-specific T cells and protection in mice. J. Gen. Virol. 69:549-559.

8. De Vries, P., J. P. M. Versteeg-van Oosten, I. K. G. Visser, R. S. Van Binnendijk, S. A. Langeveld, A. D. M. E. Osterhaus, and F. G. C. M. UytdeHaag. 1990. Measles virus-specific murine T cell clones: characterization of fine specificity and function. J. Immunol. 142:2841-2847.

9. Drillien, R., D. Spehner, A. Kirn, P. Giraudon, R. Buckland, F. Wild, and J. P. Lecocq. 1988. Protection of mice from fatal measles encephalitis by vaccination with vaccinia virus recombinants encoding either the hemagglutinin or the fusion protein. Proc. Natl. Acad. Sci. USA 85:1252-1256.

10. Fields, G. B., and R. L. Noble. 1990. Solid phase peptide synthesis utilizing 9-fluorenylmethoxycarbonyl amino acids. Int. J. Pept. Protein Res. 35:161.

11. Fleisher, A. P., H. Becht, and R. Rott. 1985. Recognition of viral antigens by human influenza $A$ virus-specific $T$ lymphocyte clones. J. Immunol. 135:800-804.

12. Giraudon, P., and T. F. Wild. 1985. Correlation between epitopes on hemagglutinin of measles virus and biological activities: passive protection by monoclonal antibodies is related to their hemagglutination inhibiting activity. Virology 144:46-58.

13. Heeg, K., W. Kuon, and H. Wagner. 1991. Immunostimulatingovalbumin complexes enter the class I MHC-restricted antigen pathway and allow sensitization against the immunodominant peptide. Eur. J. Immunol. 21:1523-1527.

14. Hill, C. M., J. D. Hayball, A. A. Allison, and J. B. Rothbard. 1991. Conformational and structural characteristics of peptides binding to HLA-DR molecules. J. Immunol. 147:189-197.

15. Huet, S., D. F. Nixon, J. B. Rothbard, A. Townsend, S. A. Ellis, and A. J. McMichael. 1990. Structural homologies between two HLA B27-restricted peptides suggest residues important for interaction with HLA B27. Int. Immunol. 2:311-316.

16. Hunt, D. F., H. Michel, T. Dickinson, J. Shabanowitz, A. L. Cox, E. Sakaguchi, A. Appella, H. M. Grey, and A. Sette. 1992. Peptides presented to the immune system by the murine class II MHC molecules I-Ad. Science 256:1817-1820.

17. Jacobson, S., J. R. Richert, W. E. Biddison, A. Satinsky, R. J. Hartzman, and H. F. McFarland. 1984. Measles virus-specific T4 human cytotoxic $\mathrm{T}$ cell clones are restricted by class II HLA antigens. J. Immunol. 133:754-757.

18. Jacobson, S., J. W. Rose, J. W., M. L. Flerlage, D. E. McFarlin, and H. F. McFarland. 1987. Induction of measles virus-specific human cytotoxic $\mathrm{T}$ cells by purified measles virus nucleocapsid and hemagglutinin polypeptides. Viral Immunol. 1:153-162.

19. Jacobson, S., R. P. Sekaly, C. L. Jacobson, H. F. McFarland, and E. O. Long. 1989. HLA class II-restricted presentation of cytoplasmic measles virus antigens to cytotoxic T cells. J. Virol. 63:1756-1762.

20. Jardetzky, T. S., W. S. Lane, R. A. Robinson, D. R. Madden, and D. C. Wiley. 1991. Identification of self peptides bound to purified HLA-B27. Nature (London) 353:326-329. 
21. Kreth, H. W., V. Ter Meulen, and G. Eckert. 1979. Demonstration of HLA restricted killer cells in patients with acute measles. Med. Microbiol. Immunol. 165:203-214.

22. Kropshofer, H., H. Max, C. A. Muller, F. Hesse, S. Stevanovic, G. Jung, and H. Kalbacher. 1992. Self-peptide released from class II HLA-DR1 exhibits a hydrophobic two-residue contact motif. J. Exp. Med. 175:1799-1803.

23. Lucas, C. J., W. E. Biddison, D. L. Nelson, and S. Shaw. 1982. Killing of measles virus-infected cells by human cytotoxic $\mathrm{T}$ cells. Infect. Immun. 38:226-232.

24. Malvoisin, E., and F. Wild. 1990. Contribution of measles virus fusion protein in protective immunity: anti-F monoclonal antibodies neutralize virus infectivity and protect mice against challenge. J. Virol. 64:5160-5162.

25. Markowitz, L. E., J. Sepulveda, J. L. Diaz-Ortega, J. L. Valdespino, P. Albrecht, E. R. Zell, J. Stewart, M. L. Zarate, and R. H. Bernier. 1990. Immunization of six-month-old infants with different doses of Edmonston-Zagreb and Schwarz measles vaccines. N. Engl. J. Med. 322:580-587.

26. Meuer, S. C., J. C. Hodgdon, D. A. Cooper, R. E. Hussey, K. A. Fitzgerald, S. F. Schlossman, and E. L. Reinherz. 1983. Human cytotoxic $\mathrm{T}$ cell clones directed at autologous virus transformed targets: further evidence for linkage of genetic restriction to T4 and T8 surface glycoproteins. J. Immunol. 131:186-192.

27. Morein, B., B. Sundquist, S. Hoglund, K. Dalsgaard, and A. D. M. E. Osterhaus. 1984. Iscom, a novel structure for antigenic presentation of membrane proteins from enveloped viruses. Nature (London) 308:457-460.

28. Morgan, A. M., S. Finerty, K. Lovgren, F. T. Scullion, and B. Morein. 1988. Prevention of Epstein-Barr (EB) virus-induced lymphoma in cottontop tamarins by vaccination with the EB virus envelope glycoprotein gp340 incorporated into immune stimulating complexes. J. Gen. Virol. 69:2093-2096.

29. Morrison, T., and A. Portner. 1992. Structure, function, and intracellular processing of the glycoproteins of Paramyxoviridae, p. 347-382. In D. W. Kingsbury (ed.), The paramyxoviruses. Plenum Press, New York.

30. Mowat, A. M. I., A. M. Donachie, G. Reid, and O. Jarrett. 1991. Immune-stimulating complexes containing Quil $\mathbf{A}$ and protein antigen prime class I MHC-restricted T lymphocytes in vivo and are immunogenic by the oral route. Immunology 72:317-322.

31. Nixon, D. F., A. R. M. Townsend, J. G. Elvin, C. R. Rizza, J. Gallway, and A. J. McMichael. 1988. HIV-1 gag-specific cytotoxic $\mathrm{T}$ lymphocytes defined with recombinant vaccinia virus and synthetic peptides. Nature (London) 336:484-487.

32. Norrby, E. 1975. Occurrence of antibodies against envelope components after immunization with formalin inactivated and live measles vaccine. J. Biol. Stand. 3:375-380.

33. Norrby, E. 1985. Measles vaccination, today and tomorrow. Ann. Inst. Pasteur/Virol. 136E:561-570.

34. Norrby, E. 1992. Immunobiology of paramyxoviruses, p. 481508. In D. W. Kingsbury (ed.), The paramyxoviruses. Plenum Press, New York.

35. Norrby, E., G. Enders-Ruckle, and V. ter Meulen. 1975. Differences in the appearance of measles virus after immunization with inactivated and live virus. J. Infect. Dis. 132:262-269.

36. Norrby, E., and Y. Gollmar. 1972. Appearance and persistence of antibodies against different virus components after regular measles infections. Infect. Immun. 6:240-247.

37. Norrby, E., C. Örvell, B. Vandvik, and J. D. Cherry. 1981. Antibodies against measles virus polypeptides in different disease conditions. Infect. Immun. 34:718-724.

38. Norrby, E., and M. N. Oxman. 1990. Measles virus, p. 10131044. In B. N. Fields et al. (ed.), Virology, vol. 1. Raven Press, New York.

39. Osterhaus, A. D. M. E., K. Weyer, F. G. C. M. UytdeHaag, O. Jarrett, B. Sundquist, and B. Morein. 1985. Induction of protective immune response in cats by vaccination with feline leukemia virus iscoms. J. Immunol. 135:591-596.

40. O'Sullivan, D., T. Arrhenius, J. Sidney, M. F. del Guercio, M. Albertson, M. Wall, C. Oseroff, S. Southwood, M. Colon, F. C. A. Gaeta, and A. Sette. 1991. On the interaction of promiscuous antigenic peptides with different DR alleles. Iden- tification of common structural motifs. J. Immunol. 147:26632669.

41. O'Sullivan, D., J. Sidney, M. F. Del Guercio, S. M. Colon, and A. Sette. 1991. Truncation analysis of several DR binding peptides. J. Immunol. 146:1240-1246.

42. Partidos, C. D., and M. W. Steward. 1990. Prediction and identification of a $\mathrm{T}$ cell epitope in the fusion protein of measles virus immunodominant in mice and humans. J. Gen. Virol 71:2099-2105.

43. Richert, J. R., J. W. Rose, C. Reuben-Burnside, M. C. Kearns, S. Jacobson, E. S. Mingioli, R. J. Hartzman, H. F. McFarland, and D. E. McFarlin. 1986. Polypeptide specificities of measles virus-reactive $T$ cell lines and clones derived from a patient with multiple sclerosis. J. Immunol. 137:2190-2194.

44. Rose, J. W., W. J. Bellini, D. E. McFarlin, and H. F. McFarland. 1984. Human cellular immune response to measles virus polypeptides. J. Virol. 49:988-991.

45. Rudensky, A. Y., P. Preston-Hurlburt, S. C. Hong, A. Barlow, and C. A. Janeway, Jr. 1991. Sequence analysis of peptides bound to MHC class II molecules. Nature (London) 353:622 627.

46. Sato, T. A., T. Kohama, and A. Sugiura. 1989. Protective role of human antibody to the fusion protein of measles virus. Microbiol. Immunol. 33:601-607.

47. Schmid, D. S. 1988. The human MHC-restricted cellular response to herpes simplex virus type I is mediated by $\mathrm{CD} 4+$, CD8- T cells and is restricted to the DR region of the MHC complex. J. Immunol. 140:3610-3617.

48. Sethi, K. K., I. Stroehmann, and H. Brandis. 1982. Generation of cytolytic T-cell cultures displaying measles virus specificity and human histocompatibility leukocyte antigen restriction. Infect. Immun. 36:657-661.

49. Takahashi, H., T. Takeshita, B. Morein, S. Putney, R. N. Germain, and J. A. Berzofsky. 1990. Induction of CD8+ cytotoxic T cells by immunization with purified HIV-1 envelope protein in ISCOMs. Nature (London) 344:873-875.

50. Townsend, A., and H. Bodmer. 1989. Antigen recognition by class I-restricted T lymphocytes. Annu. Rev. Immunol. 7:601624.

51. Trudel, M., G. Boulay, C. Sequin, F. Nadon, and G. Luisser. 1988. Control of infectious bovine rhinotracheitis in calves with a BHV-1-ISCOM vaccine. Vaccine 5:525-529.

52. Van Binnendijk, R. S., M. C. M. Poelen, P. De Vries, H. O. Voorma, A. D. M. E. Osterhaus, and F. G. C. M. UytdeHaag. 1989. Measles virus-specific human T cell clones. Characterization of specificity and function of CD4+ helper/cytotoxic and CD8+ cytotoxic T cell clones. J. Immunol. 142:2847-2854.

53. Van Binnendijk, R. S., M. C. M. Poelen, K. C. Kuijpers, A. D. M. E. Osterhaus, and F. G. C. M. UytdeHaag. 1990. The predominance of $\mathrm{CD} 8+\mathrm{T}$ cells after infection with measles virus suggests a role for $\mathrm{CD} 8+$ class I MHC-restricted cytotoxic $T$ lymphocytes (CTL) in recovery from measles. Clonal analyses of human CD8+ class I MHC-restricted CTL. J. Immunol. 144:2394-2399.

54. Van Binnendijk, R. S., C. A. van Baalen, M. C. M. Poelen, P. De Vries, J. Boes, V. Cerundolo, A. D. M. E. Osterhaus, and F. G. C. M. UytdeHaag. 1992. Measles virus transmembrane fusion protein synthesized de novo or presented in ISCOM is endogenously processed for HLA class I- and II-restricted cytotoxic T cell recognition. J. Exp. Med. 176:119-128.

55. Varsanyi, T. M., B. Morein, A. Löve, and E. Norrby. 1987. Protection against lethal measles virus infection in mice by immune-stimulating complexes containing the hemagglutinin or fusion protein. J. Virol. 61:3896-3901.

56. Visser, I. K. G., M. W. G. Van de Bildt, H. Brugge, P. J. H. Reijnders, E. J. Vedder, P. De Vries, J. Groen, H. C. Walvoort, F. G. C. M. UytdeHaag, and A. D. M. E. Osterhaus. 1989. Vaccination of harbour seals (Phoca vitulina) against phocid distemper virus with two different inactivated canine distemper vaccines. Vaccine 7:521-526.

57. Whittle, H. C., G. Mann, M. Eccles, L. Hanlon, G. Mann, K. O'Neill, P. Hanlon, and V. Marsh. 1988. Effects of dose and strain on success of measles vaccination in infants aged 4-5 
months. Lancet ii:811-814.

58. Wiertz, E. J. H. J., J. A. M. van Gaans-van den Brink, H. Gausepohl, A. Prochnicka-Chalufour, P. Hoogerhout, and J. T. Poolman. 1992. Identification of $\mathrm{T}$ cell epitopes occurring in a meningococcal class I outer membrane protein using overlapping peptides assembled with simultaneous multiple peptide synthesis. J. Exp. Med. 176:79-88.

59. Wild, F., P. Giraudon, R. Spehner, R. Drillien, and J. P. Lecocq. 1990. Fowlpox virus recombinant encoding the measles virus fusion protein: protection of mice against fatal measles encephalitis. Vaccine 8:441-442.

60. Yasukawa, M., and J. M. Zarling. 1984 . Human cytotoxic T cell clones directed against herpes simplex virus-infected cells. I. Lysis restricted by HLA class MB and DR antigens. J. Immunol. 133:422-427.

61: Yewdell, J. W., and J. R. Bennink. 1990. The binary logic of antigen processing and presentation to T cells. Cell 62:203-206. 